DOI https://doi.org/10.30525/978-9934-26-173-2-39

\title{
РОЛЬ ІНТЕРАКТИВНИХ ТЕХНОЛОГІЙ У ПІДВИЩЕННІ НАВЧАЛЬНОЇ МОТИВАЦІЇ СТУДЕНТІВ
}

\author{
Димар Н. М. \\ асистент кафедри біології \\ Національний медичний університет імені О. О. Богомольияя \\ м. Київ, Украӥна \\ Матківська Р. М. \\ кандидат медичних наук, \\ дочент, дочент кафедри описової та клінічної анатомії \\ Національний медичний університет імені О. О. Богомольияя \\ м. Київ, Украӥна
}

Тенденції розвитку сучасного освітнього середовища європейського простору спонукають до формування нових стандартів вищої освіти і в Україні. На сьогоднішній день інформаційно-комунікаційні та інтерактивні технології поступово, але впевнено, займають місце серед інноваційних методів як наукової так і навчальної діяльності закладів вищої освіти, які намагаються забезпечити усім необхідним студентів для збереження і підвищення їхньої мотивації до навчання. Сприяння росту мотивації студентів не дарма стало однією з основних проблем дослідників у галузі освіти, оскільки саме мотивація до навчання являється одним із ключових чинників, які безпосередньо впливають на бажання опановувати новими знаннями [7, с. 129]. Застосування інтерактивних технологій навчання під час вивчення студентами навчальних дисциплін передбачає участь кожного із них у процесі пізнання та активізує їх творчу діяльність. Вивчення можливостей застосування інтерактивних технологій та їх впливу на мотивацію студентів набуває все більшої актуальності, особливо під час впровадження дистанційної та змішаної форми навчання в умовах погіршення епідеміологічної ситуації у світі.

На думку багатьох дослідників, мотивація являє собою систему природних та соціальних чинників, які спонукають студентів долучатися до навчального процесу, і завдяки яким цей процес набуває ефективності [3, с. 36]. У педагогічній системі мотивація виступає одним із найвагоміших чинників, які впливають на ефективність засвоєння знань [6, с. 118]. Мотивацію до навчання можна поділити на зовнішню i внутрішню, враховуючи типи стимулів, які пробуджують бажання до навчальної діяльності [7, с 130]. В той же час, можна виділити 
інтегративну та інструментальну мотивацію, враховуючи чи індивід здійснює певний вид діяльності для задоволення особистих потреб чи для досягнення практичних цілей. Найбільш успішним результатом діяльності можна вважати такий, який отримано при поєднанні усіх типів мотивації.

Досвідчені викладачі зазначають, що успішно оволодіти знаннями може лише той, хто керується внутрішньою мотивацією до навчання, а навчити студента, який не має жодної мотивації, фактично неможливо. Варто зазначити, що здобувачі освіти з високою успішністю та ті, чиї результати навчання значно нижчі, відрізняються не інтелектуальним рівнем, а саме рівнем мотивації до навчальної діяльності. Досить часто високий рівень мотивації дозволяє швидко компенсувати недостатність теоретичних знань, сприяти набуттю практичних навичок та вмінь. У той же час, саме недостатній рівень мотивації, відсутність бажання навчатись перешкоджає досягненню успіху. Висока мотивація студентів до навчання забезпечує їх ефективне залучення до всього навчального процесу, а роль викладача полягає у створенні фундаменту для їі формування [1, с. 41].

До засобів формування мотивації відносять творчі завдання, які активізують уяву студентів та спонукають до критичного мислення, вправи та ситуаційні задачі, що імітують майбутню професійну діяльність, відкриті лекції, семінари, конференції із особами, які досягли успіху у даній галузі, широке застосування у навчальному процесі інтерактивних технологій [3, с. 42].

Використання інтерактивних технологій під час організації навчальної діяльності студентів передбачає створення таких умов для студентів, де кожен відчував би свою успішність та інтелектуальне зростання [2, с.41]. Інтерактивні технології як джерело підвищення мотивації до навчання стимулюють студентів до пізнавальної діяльності та набуття нових професійних навиків. Під час проведення навчальних занять 3 використанням інтерактивних технологій важливим $\epsilon$ уникання домінування суб'єктів навчальної діяльності один над одним, а результативна взаємодія «викладач-студент» можлива лише за умови позитивної їх співпраці. Метою такої форми навчання є постійна та активна взаємодія між викладачем та студентами, підтримка рівноправності при розв'язанні важливих для кожного здобувача освіти практичних завдань, співпраця між студентами, а також роль викладача як наставника. Під час спілкування на заняттях студенти навчаються аналізувати разом складні завдання, конструктивно дискутувати, висловлювати альтернативну думку, моделювати проблемну ситуацію, приймати виважені рішення, розв’язувати конфліктні ситуації, будувати 
взаємовідносини у колективі, i таким чином розвивають навички командної роботи [5, с. 141].

Застосування інтерактивних технологій є найбільш ефективним при організації групових дискусій під час обговорення змодельованих ситуацій із майбутньої професійної діяльності, у проектній діяльності при виконанні студентами індивідуальних завдань, а також при створенні інформаційних навчальних ресурсів. Для забезпечення якості навчального процесу та підвищення мотивації студентів до набуття та закріплення нових знань доцільно використовувати такі інтерактивні технології як тренінг, кейс-метод, мозковий штурм, конференція, круглий стіл. В сучасних умовах, досягнення у сфері інформаційно-комунікаційних технологій дозволяють застосовувати такі методи навчання не лише аудиторно, але і дистанційно при проведенні онлайн занять у формі вебінару [4]. Важливим етапом проведення навчальних занять за допомогою інтерактивних технологій є формування завдань і навчальних задач, основною метою яких є не лише вивчити новий матеріал, а й закріпити його на практиці. При цьому необхідною умовою $є$ саме залучення усіх студентів групи до активної та спільної навчальної діяльності, оскільки за таких умов кожен студент може зробити свій інтелектуальний внесок для вирішення спільного завдання та збагатити свої знання в ході обговорення. Таким чином застосування інтерактивних технологій сприяє підвищенню мотивації студентів - бажання отримати задоволення та практичну користь від отриманих під час навчальних занять нових знань. Можна виокремити такі типи мотивації, на підвищення формування яких значно впливає застосування інтерактивних технологій:

- спонукальна - мотивація, основою якої $\epsilon$ авторитетна думка батьків, наставників, друзів;

- пізнавальна - отримання позитивних емоцій від процесу пізнавальної діяльності та засвоєння нових знань під час навчальних занять;

- професійно-ціннісна - прагнення студентів отримати професійну підготовку належного рівня для достойного працевлаштування;

- соціальна - бажання отримати високий соціальний статус у суспільстві завдяки отриманій освіті.

Як невід'ємний компонент освітнього процесу, вмотивованість кожного студента до набуття нових знань $є$ дуже індивідуальною i залежить, звичайно, від внутрішніх прагнень та переконань, проте формування зовнішньої мотивації залежить саме від викладача, його майстерності, уміння застосовувати та комбінувати різноманітні 
педагогічні методи та прийоми, імплементувати у навчальний процес інтерактивні технології.

Таким чином, застосування інтерактивних технологій у навчальному процесі забезпечує якісне викладання навчальних дисциплін, сприяє підвищенню мотивації до навчання студентів, всебічному розвитку їх особистості i, як наслідок, підготовку висококваліфікованих фахівців, успішних на ринку праці.

\section{Література:}

1. Гончарук Л.М., Рябокучма Т.О., Хмель О.В. Мотивація курсантів до вивчення іноземної мови як основа якісної професійної підготовки. Sciences of Europe. 2020. № 48 (4). С. 41-43.

2. Гула Л.В. Впровадження інтерактивних технологій у вищих навчальних закладах. АОГОГ: Збірник наукових пращь. 2019. Т. 5. C. 41-45.

3. Дзюбко Л.В., Гриценок Л.І. Мотивація навчальної діяльності як психолого-педагогічна проблема. Психодіагностика. 2009. Вип. 4. C. 33-43.

4. Димар Н.М. Вебінар як форма навчання під час опанування студентами медичної біології. Інноваційна педагогіка. Вип. 39. 2021. C. 278-282. URL: http://www.innovpedagogy.od.ua/archives/2021/39/59.pdf

5. Остапчук Д., Мирончук Н.М. Інтерактивні методи навчання у вищих навчальних закладах. Модернізація вищої освіти в Україні та за кордоном. 2014. C. 140-143.

6. Dornyei Z. Motivation in second and foreign language learning. Language Teaching. 1998. № 31. P. 117-135.

7. Honcharuk L., Riabokuchma T., Kryński A. Ways of increasing motivation of cadets to learn a foreign language. Scientific Journal of Polonia University. 2020. 40 (3). P. 129-133. 